\title{
MOTIVASI KERJA, LOYALITAS, DAN KUALITAS KARYAWAN TERHADAP KINERJA KARYAWAN PT. VARIA USAHA GRESIK
}

\author{
SOFIYAH EKA ALFIYAH \\ Jurusan Manajemen, Fakultas Ekonomi, Universitas Negeri Surabaya \\ Kampus Ketintang, Surabaya 60231 \\ E-mail: sofiyaekaalfiah@gmail.com
}

\begin{abstract}
This study to analyze the influence of work motivation, loyalty, employee quality to the employee performance in PT. Varia Usaha Gresik. The samples from this study are all permanent employees of Varia Usaha Gresik company amount to 96 employees. The sampling technique used is saturated sampling method, data analyze technique used multiple linear regression analysis with the assistance of SPSS 18.0. the study to analyze the influence of work motivation did not have a significant effect to the employee. The loyalty and employee quality significant influence to the employee performance. Work motivation, loyalty, employee quality has simultan and significant influence to employee performance.
\end{abstract}

Keywords: work motivation, loyalty and employee quality.

\section{PENDAHULUAN}

Dewasa ini karyawan dipandang sebagai salah satu aset perusahaan yang penting dan perlu dikelola serta dikembangkan untuk mendukung kelangsungan hidup perusahaan untuk Matutina (2001:205) memenangkan persaingan, dunia bisnis, setiap perusahaan harus mempunyai keunggulan kompetitif yang sangat sulit ditiru, yang hanya akan diperoleh dari karyawan yang memiliki pengetahuan (knowledge), keterampian (skill), dan kemampuan (abilities). Salah satu yang memenuhi kriteria seperti itu hanya akan dimiliki melalui penerapan konsep dan teknik manajemen sumber daya manusia yang tepat dengan lingkungan kerja yang mendukung.

Menurut Herzberg (1966) dalam Handoko (2010) ada dua jenis faktor yang mendorong seseorang untuk berusaha mencapai kepuasan dan menjauhkan diri dari ketidakpuasan. Dua faktor itu disebutnya factor hygiene (faktor ekstrinsik) dan faktor motivator (faktor intrinsik). Faktor hygiene memotivasi seseorang untuk keluar dari ketidakpuasan, Faktor eksternal tersebut termasuk gaji, keamanan kerja, kondisi kerja, pengawasan, hubungan interpersonal, kebijakan dan administrasi, faktor motivator memotivasi seseorang untuk berusaha mencapai kepuasan, yang termasuk didalamnya adalah pencapaian atau penyelesaian pada suatu pekerjaan, pengenalan untuk menyelesaikan pekerjaan, sifat pekerjaan dan tugas itu sendiri, kelanjutan dan pertumbuhan dalam kemampuan pekerjaan. Faktor-faktor motivasi yang bersifat internal dengan pekerjaan seperti prestasi, pengakuan, tanggung jawab, sifat pekerjaan dan pertumbuhan pribadi dan kemajuan secara signifikan berhubungan dengan kerja karyawan. (Ncube dan Samuel, 2014) dalam Achmad (2006). Motivasi merupakan suatu proses yang membangkitkan, mengarahkan dan menjaga atau memelihara perilaku manusia agar terarah pada tujuan. Untuk lebih meningkatkan peformance dan sikap positif, sebaiknya menggunakan dan berpusat pada faktor faktor motivator.

Pekerjaan seharusnya dirancang sedemikian rupa sehingga menghasilkan derajat penghargaan yang tinggi oleh kedua faktor tersebut. Faktor hygiene untuk menghindari ketidakpuasan kerja karyawan dan motivator sebagai faktor yang memastikan kepuasan kerja karyawan. Untuk menumbuhkan tingkat kesadaran karyawan dalam melaksanakan tugas yang telah dibebankan, sebaiknya karyawan juga diberikan motivasi agar setiap karyawan memiliki dorongan dalam menyelesaikan tugas sesuai tangung jawab. Bentuk motivasi yang diberikan perusahaan untuk karyawan 
dengan kebijakan yang telah ditentukan PT. Varia Usaha Gresik dalam meningkatkan kinerja maka perusahaan memberikan penghargaan berupa (reward) ada beberapa macam penghargaan sebagai berikut : Kenaikan tingkat golongan, Kenaikan jabatan, Karyawan teladan, Karyawan berprestasi, Kesetiaan karyawan pada masa kerja 10, 15, 25, 30, 35 tahun penghargaan yang diterima dari kesetiaan selama masa kerja yang dilakukan penghargaan yaitu berupa emas batangan tetapi diuangkan dengan senilai emas batangan yang telah diterima, dan penghargaan cuti tahunan dan cuti hari besar.

Beberapa penelitian seperti Utomo (2011), Utomo (2010), Abonam (2011), Umar (2012), Muogbo (2013) membuktikan bahwa motivasi berpengaruh positif dan signifikan terhadap kinerja. Hasil penelitian Johannes (2014) menunjukan bahwa ada pengaruh yang kuat pada kinerja disebabkan perubahan cara motivasi yang dilakukan oleh manajemen. Selain faktor motivasi kerja, loyalitas dan kualitas karyawan merupakan salah satu faktor yang berperan dalam meningkatnya kinerja seorang karyawan.

Beberapa hal yang menyebabkan turunnya tingkat loyalitas karyawan yaitu upah yang mereka terima tidak sesuai dengan pekerjaannya, tidak cocoknya dengan gaya perilaku pemimpin, lingkungan kerja yang buruk dan sebagainya. Untuk memecahkan persoalan tersebut, maka perusahaan harus menemukan penyebab dari turunnya loyalitas dan sikap kerja karyawan itu disebabkan pada prinsipnya. Turunnya loyalitas dan sikap kerja karyawan itu disebabkan oleh penempatan karyawan yang kurang tepat yang menyebabkan terhambatnya produktivitas karyawan terutama bagi yang memiliki kepuasan dan produktivitas kerja yang tinggi. Ini mengakibatkan karyawan cenderung malas dan bahkan berakibat karyawan itu berhenti bekerja.

Secara duniawi, kehidupan yang sulit membuat orang harus bekerja keras untuk tetap hidup, Biasanya orang-orang dengan sikap kerja ini memiliki loyalitas yang kuat terhadap organisasi dan tujuannya. Studi di berbagai perusahaan menunjukkan bahwa sikap tersebut menimbulkan tanggung jawab moral dari pada sekadar urusan bisnis secara rasional (Davis dan Newstorm, 1989). Menurut Sheldon (dalam Steers dan Porter, 1983) mengemukakan bahwa loyalitas merupakan suatu orientasi terhadap organisasi yang berkaitan dengan identifikasi seseorang terhadap organisasinya.

Bitner dan Zeithaml (dalam Riorini, 2004:22) menyatakan untuk dapat meningkatkan kualitas kerja ada beberapa cara yang dapat dilakukan oleh perusahaan yaitu dengan memberikan pelatihan atau training, memberikan insentive atau bonus dan mengaplikasikan atau menerapkan teknologi yang dapat membantu meningkat. Penelitian seperti Preko (2013), Setiyono (2009), Hamzah (2013). Membuktikan bahwa loyalitas berpengaruh signifikan pada kinerja karyawan. Bitner dan Zeithaml (dalam Riorini, 2004:22) menyatakan untuk dapat meningkatkan kualitas kerja ada beberapa cara yang dapat dilakukan oleh perusahaan yaitu dengan memberikan pelatihan atau training, memberikan insentive atau bonus dan mengaplikasikan atau menerapkan teknologi yang dapat membantu meningkatkan efisiensi dan efektifitas kerja.

Penelitian menurut Nadirsyah (2010) menyatakan bahwa kualitas karyawan benpengaruh signifikan terhadap kinerja karyawan penelitian ini juga didukung oleh Osland (2011). Peneliti dapat menyimpulkan bahwa motivasi kerja yang di berikan perusahaan kepada karyawan sangat baik perusahaan memberikan reward yang begitu besar agar karyawannya bekerja dengan baik akan tetapi kenyataan yang didapat kinerja mereka menurun.

Motivasi ini sangat berkaitan dengan kebutuhan sehingga manajemen perusahaan harus lebih perhatian terhadap kebutuhan karyawannya agar bisa memotivasi mereka dengan baik. Selain itu, dengan menciptakan lingkungan kerja yang sesuai harapan karyawan, akan membuat mereka merasa nyaman dalam bekerja. Oleh karena itu faktor motivasi, loyalitas dan kualitas karyawan akan menjadi faktor yang dapat menjadikan karyawan mencapi kepuasan dalam bekerja sehingga dapat meningkatkan kinerja yang berarti bagi perusahaan. 
Imbalan yang memadai, berupa imbalan financial dan dalam bentuk penghargaan kepada karyawan serta upaya pemenuhan kebutuhan berupa pemberian dorongan kepada setiap karyawan untuk memperoleh hasil kerja yang memuaskan, bagi karyawan yang pekerjaannya memuaskan dapat diberikan penghargaan yang wajar. Hal ini menunjukan tidak hanya imbalan financial yang diterima, tetapi mungkin saja peningkatan status kepegawaiannya, promosi, kesempatan memperoleh tingkat kesejateraan guna peningkatan status yang memadai. Oleh karena itu, dengan adanya motivasi kerja yang tinggi akan mendorong semangat dan gairah kerja karyawan dalam melaksanakan tugasnya.

Berdasaran observasi dan wawancara dengan kepala biro sumber daya manusia dan selaku karyawan menyatakan, fenomena yang terjadi di PT.Varia Usaha adalah mengenai motivasi yang dimiliki karyawan adalah sangat besar akan tetapi kinerja mereka menurun, loyalitas juga demikian, loyalitas yang dimiliki karyawan sangat tinggi tetapi pekerjaan yang mereka selesaikan sangat jauh dari kata benar. Sedangkan untuk kualitas karyawan di PT. Varia Usaha adalah ada dua pendapat yang dikemukan yakni kualitas karyawan baik tetapi tidak menjadikan kinerjanya mereka baik.

Berdasarkan fenomena dan penelitian yang telah disebutkan sebelumnya menjadi alasan penulis untuk melakukan penelitian mengenai pengaruh motivasi, loyalitas, dan kualitas karyawan terhadap kinerja karyawan di pt. varia usaha gresik.

\section{KAJIAN PUSTAKA}

Motivasi Kerja

Menurut Hasibuan (2003:92) motivasi berasal dari kata latin movere yang berarti dorongan atau daya penggerak. Motivasi adalah dorongan yang timbul pada diri seseorang untuk melakukan tindakan karena ingin mencapai tujuan yang dikehendakinya. Proses pemberian dorongan dilakukan kepada karyawan supaya dapat bekerja guna mencapai tujuan perusahaan. Sementara itu Menurut Cleland yang dikutip oleh Gibson (2001:76) terdapat tiga macam kebutuhan yang perlu diperhatikan pegawai yaitu kebutuhan akan prestasi, kebutuhan akan kelompok pertemanan, kebutuhan akan kekuasaan.

Motivasi merupakan kerangka kerja lain untuk memahami motivasional dari lingkungan kerja dan ada dua faktor yaitu faktor motivator yang mencangkup Pekerjaan itu sendiri, kesempatan berprestasi, kesempatan untuk memperoleh kemajuan atau berkembang dan yang kedua kelompok dissatisfier mencangkup lingkungan kerja, kebijakan perusahaan, peraturan, upah/ gaji Herzberg yang dikutip oleh Ruky (2006:4).

Berdasarkan beberapa pendapat para ahli dapat disimpulkan bahwa motivasi kerja adalah kesempatan yang diberikan kepada kepada karyawanya untuk lebih maju, dan naiknya motivasi kerja dipengaruhi oleh pekerjaan itu sendiri, kesempatan berprestasi, kesempatan untuk memperoleh kemajuan atau berkembang, lingkungan kerja, kebijakan perusahaan, kebutuhan akan kekuasaan, peraturan dan upah / gaji.

\section{Loyalitas}

Menurut Budiman (2009) Loyalitas berasal dari kata dasar loyal yang memiliki arti setia atau patuh. Loyalitas berarti mengikuti dengan patuh dan setia terhadap seseorang atau sistem/peraturan. Istilah loyalitas ini sering didefinisikan bahwa seseorang akan disebut loyal atau memiliki loyalitas yang tinggi jika mau mengikuti apa yang diperintahkan. Sedangkan menurut Saydam (2000:484) karakteristik loyalitas dapat dilihat dari ketaatan atau kepatuhan, bertanggung jawab, pengabdian, dan kejujuran. Seseorang dikatakan memiliki loyalitas yang tinggi apabila orang tersebut memiliki karakteristik pribadi, karakteristik pekerjaan, Karakteristik desain perusahaan., Pengalaman yang diperoleh dari perusahaan.

Berdasarkan pendapat dari beberapa ahli yang menyimpulkan loyalitas adalah kepatuhan atau kesetiaan yang dimiliki karyawan untuk perusahannya. Karyawan yang memiliki rasa loyal yang tinggi terhadap perusahannya dapat dilihat atau diukur dari ketaatan atau kepatuhan, bertanggung jawab, pengabdiaanya, dan kejujuranya. Orang -orang tersebut pastinya memiliki karakteristik pribadi yang tinggi, karakteristik pekerjaan yang sanggat tinggi 
serta memiliki pengalaman yang diperoleh dari perusahaan.

\section{Kualitas Karyawan}

Menurut (Prawirosentono ; 1999 : 47)

kualitas karyawan adalah karyawan yang bisa melakukan pekerjaan dengan baik, bisa mencapai tujuan organisasi dan bisa bekerja secara perorangan (individual performance) dan kinerja organisasi (corporate performance), karena ada hubungan yang erat antara Kinerja karyawan (individual performance) dan (corporate performance) apabila keduanya dilakukan dengan bersamasama dan terjalin baik maka kinerja mereka akan berjalan dengan baik. Sedangkan menurut Matutina (2001:205) menyatakan kualitas kerja karyawan mengacu pada kualitas sumber daya manusia. Kualitas sumber daya manusia mengacu pada pengetahuan (knowledge) yaitu kemauan yang dimiliki karyawan, keterampilan (Skill) yaitu kemampuan dan penguasaan teknis operasional dibidang tertentu yang dimiliki karyawan, kemauan (abilities) yang terbentuk dari sejumlah kompetensi yang dimiliki seorang karyawan, hubungan kualitas kerja dihasilkan oleh perpaduan antara kemampuan (ability) dan kemauan (motivasi). Seorang karyawan yang mempunyai kemampuan dan kemauan akan menghasilkan kualitas yang baik.

Berdasarkan beberapa pendapat para ahli dapat disimpulkan bahwa kualitas karyawan adalah kemampuan karyawan dalam bekerja, baik bekerja secara individu maupun bekerja dengan kelompoknya. Kualitas karyawan mengacu pada keterampilan yang dimiliki, kemampuan yang terbentuk dari sejumlah kopetensi, kualitas kerja yang dihasikan dan kemampuan karyawan yang bisa memotivasi dirinya sendiri untuk melakukan kinerja yang baik.

\section{Kinerja Karyawan}

Menurut Hasibuan, menyatakan kinerja merupakan perwujudan kerja yang dilakukan oleh karyawan yang biasanya dipakai sebagai dasar penilaian terhadap karyawan atau organisasi. Kinerja yang baik merupakan langkah untuk tercapainya tujuan organisasi. Sedangkan menurut (Mangkunegara, 2008:67) Kinerja karyawan adalah tingkat pencapaian hasil atas pelaksanaan tugas tertentu seorang karyawan. Manajemen kinerja adalah keseluruhan kegiatan yang dilakukan untuk meningkatkan kinerja perusahaan atau organisasi, termasuk kinerja masing-masing individu dan kelompok kerja di perusahaan tersebut. Kinerja karyawan merupakan hasil pekerjaan baik secara kualitas maupun kuantitas yang dapat dicapai dan dilakukan oeh seseorang pegawai dalam melaksanakan tugas dan mengembangkan tanggung jawab yang diberikan oleh atasan. Malthis (2001:378).

Berdasarkan beberapa pendapat para ahli dapat disimpulkan bahwa kinerja karyawan adalah perwujutan atau hasil yang dilakukan karyawan untuk perusahaanya baik secara kualitas maupun kuantitas yang dapat dicapai dan untuk kesejahteraan perusahaan.

\section{Motivasi Kerja dan Kinerja Karyawan}

Motivasi adalah dorongan yang timbul pada diri seseorang untuk melakukan tindakan karena ingin mencapai tujuan yang dikehendakinya. Proses pemberian dorongan dilakukan kepada karyawan dengan cara karyawan di pengaruhi oleh pekerjaan itu sendiri, kesempatan berprestasi, kesempatan untuk memperoeh kemajuan atau berkembang, lngkungan kerja, kebijakan perusahaan, peraturan dan upah/gaji, motivasi ini diberikan agar karyawan dapat bekerja dengan baik guna mencapai tujuan perusahaan. Pernyataan tersebut didukung oleh penelitian Umar (2011) dalam hasil penelitiannya menunjukkan bahwa karyawan yang memiliki motivasi yang tinggi berpengaruh terhadap upah, motivasi dan kepuasan kerja memiliki prioritas utama agar karyawan memiliki kinerja yang baik

Hasil penelitin Nitasari (2012) menunjukkan bahwa ada hubungan signifikan antara alat motivasi seperti upah, kepuasan kerja dan kinerja mereka. Utomo (2010) juga telah mendukung upaya penelitian ini, karena hipotesis bahwa dengan upah yang tinggi maka kinerja juga ikut meningkat serta kepuasan kerja mendukung karyawan untuk menyelesaikan pekerjaannya dengan baik.

Motivasi kerja akan mempengaruhi kinerja karyawan, didukung dengan teori dua 
faktor yang dikemukakan oleh Herzberg yang dikutip oleh Ruky (2006:4) yang menyebutkan naiknya motivasi kerja karyawan di pengaruhi oleh pekerjaan itu sendiri, kesempatan berprestasi, kesempatan untuk memperoeh kemajuan atau berkembang, lngkungan kerja, kebijakan perusahaan, peraturan dan upah/gaji.

\section{Loyalitas dan Kinerja Karyawan}

Loyalitas adalah sikap yang patuh dan setia terhadap perusahaanya, loyalitas karyawan berpengaruh terhadap kinerja karyawan dan loyalitas karyawan dapat diukur dari hasil kinerja, ketaatan atau kepatuhan, bertanggung jawab, pengabdian dan kejujuran pernyataan tersebut didukung oleh penelitian Preko (2013) dalam hasil penelitiannya menunjukkan bahwa loyalitas berpengaruh terhadap kinerja karyawan dengan dipengaruhi hubungan karyawan, gaya kepemimpinan, pengembangan pribadi, dan hasil kinerja.

Hasil penelitian Hamzah (2013) juga telah mendukung upaya penelitian ini , karena senioritas karyawan dan loyalitas karyawan berpengaruh terhadap karyawan dimana senioritas adalah jenjang terhadap kinerja serta kualitas adalah tingkat seseorang karyawan untuk melihat kinerja karyawan. Selain itu, loyalitas, motivasi dan budaya kerja berpengaruh terhadap kemajuan karyawan untuk mengerjakan tugasnya dengan baik serta bagaimana karyawan itu bisa memecahkan masalah dalam pekerjaanya).

\section{Kualitas Karyawan dan Kinerja Karyawan}

Kualitas karyawan adalah kemampuan yang dimiliki karyawan untuk menyelesaikan pekerjaanya, kualitas karyawan dapat dilihat dari kemampuan atau keahlian dalam melaksanakan pekekerjaanya, kualitas karyawan sangatlah penting untuk keberlasungan perusahaan. Karyawan yang mimiliki kualitas baik harus bisa bekerja secara individu maupun bekerja dengan kelompok. Pernyataan tersebut didukung oleh penelitian Herijon (2011) yang menyatakan kualitas karyawan, budaya organisasi serta komitmen organisasi sangat berpengaruh terhadap kinerja karyawan akademi parawisata.
Hasil penelitian Nadirsyah (2010) menunjukan bahwa ada hubungan penelitian, Penelitian ini meneliti tentang pengaruh kualitas terhadap kinerja karyawan hasil penelitian adalah kualitas berpengaruh signifikan positif terhadap kinerja karyawan, selain itu penelitian ini meneliti hubungan motivasi kerja dan lingkungan kerja yang saling terkait dengan kinerja karyawan dan hasilnya adalah motivasi kerja dan lingkungan kerja berpengaruh terhadap kinerja karyawan.

Tinggi rendahnya kualitas karyawan sangatlah berpengaruh terhadap kinerja karyawan, karyawan yang memiliki kemampuan yang tinggi pastinya kinerja mereka juga baik, didukung dengan teori Matutina (2001:205) menyebutkan karyawan yang memiliki kualitas kerja yang baik haruslah memiliki pengetahuan (knowledge), keterampilan (skill), kemampuan (abilities), dan hubungan kualitas kerja dihasilkan oleh perpaduhan antara kemampuan (ability).

\section{HIPOTESIS}

Berdasarkan teori dari beberapa ahli tersebut serta didukung oleh penelitian terdahulu, maka disusun hipotesis penelitian sebagai berikut:

H1: Ada pengaruh yang positif signifikan antara Motivasi kerja (X1) terhadap kinerja karyawan (Y).

$\mathrm{H} 2$ : Ada pengaruh yang positif signifikan antara Loyalitas (X2) terhadap Kinerja Karyawan (Y).

H3: Ada pengaruh yang positif signifikan antara Kualitas (X3) terhadap Kinerja Karyawan (Y).

H4: Ada pengaruh yang positif signifikan antara motivasi $\operatorname{kerja}(\mathrm{X} 1)$, Loyalitas(X2), dan Kualitas Karyawan(X3) terhadap Kinerja Karyawan(Y).

\section{METODE PENELITIAN}

Penelitian ini menggunakan pendekatan kuantitatif. Menurut Sugiyono (2010:14) metode penelitian kuantitatif dapat diartikan sebagai metode yang berlandaskan pada filsafat positivisme, digunakan untuk meneliti pada populasi atau sampel tertentu, teknik pengambilan sampel pada umumnya dilakukan secara random, pengumpulan data 
menggunakan instrumen penelitian, analisis data bersifat kuantitatif atau statistik dengan tujuan untuk menguji hipotesis yang telah ditetapkan.

Populasi yang menjadi objek penelitian adalah seluruh karyawan tetap PT. Varia Usaha Gresik yang berjumlah 96 orang. Keseluruhan populasi digunakan sebagai sampel karena jumlah karyawan tersebut masih dapat dijangkau seluruhnya untuk dilakukan penelitianPenelitian ini menggunakan tiga varabel, yaitu variabel motivasi kerja, loyalitas, dan kualitas karyawan dan variabel terikatnya dalah kinerja karyawan.

Motivasi kerja merupakan dorongan yang diberikan perusahaan kepada karyawanya, agar karyawan memiliki kinerja yang baik. Pada penelitian ini, karakteristik Herzberg yang dikutip Ruky (2006:4) digunakan untuk mengukur variabel motivasi kerja yaitu untuk mengukur motivasi kerja yang terdiri dari pekerjaan itu sendiri, kesempatan berprestasi, kesempatan untuk memperoleh kemajuan atau berkembang, lingkungan kerja, kebijakan perusahaan, peraturan, upah atua gaji.

Loyalitas adalah sikap setia atau patuh yang dimiliki karyawan untuk perusahaanya. Pada penelitian ini. Karakteristik Syadam (2000:484) digunakan untuk mengukur variabel loyalitas yaitu ketaatan, kepatuhan, bertangung jawab, pengabidian dan kejujuran.

Kualitas karyawan adalah kemampuan yang dimiliki karyawan untuk menyelesaikan pekerjaanya. Pada penelitian ini karakterstik Matutina (2001:205) digunakan untuk mengukur variabl kualitas karyawan yaitu pengetahuan (knowledge), keterampilan (skill), kemampuan (abilities), dan hubungan kualitas kerja dihasilkan oleh perpaduhan antara kemampuan (ability).

Kinerja karyawan adalah hasil perwujutan kerja yang dicapai yang dilakukan oleh karyawan. Karakteristik Rivai (dalam Setiyono,2009) digunakan untuk mengukur variabel kinerja karyawan yaitu kemampuan teknis, kemampuan konseptual, kemampuan hubungan interpersonal.

Teknik pengumpulan data yang digunakan penelitian ini adalah kuesioner, dokumentasi, observasi dan wawancara, Wawancara dilakukan pada pimpinan biro sumber daya manusi PT. Varia Usaha Gresik sebagai sumber informasi yang berhubungan dengan penelitian ini. Kuesioner disebarkan secara langsung kepada semua responden yaitu karyawan tetap PT. Varia Usaha Gresik. Pada penelitian ini skala penelitian ini berupa skala likert, umumnya masingmasing item skala mempenyai lima katagori, yangberisar antara "sangat setuju" sampai dengan "sangat tidak setuju" Sugiyono (2009:94). Teknik analisis data dalam penelitian ini menggunakan analisis regresi linier berganda dan koefisien determinasi dengan menggunakan alat bantu SPSS 18.0. Sedangkan teknik analisis yaitu analisis deskriptif menggunakan tiga katagori rendah, sedang, tinggi Azwar (2012:149).

\section{HASIL DAN PEMBAHASAN}

Responden dalam penelitian ini adalah karyawan tetap PT. Varia Usaha Gresik.. Dari 96 kuesioner yang disebar, 96 kuesioner telah kembali dalam keadaan terisi. Hasilnya sebagian besar responden terdiri dari 61 karyawan atau $63,5 \%$ berjenis kelamin lakilaki dan sebanyak 35 karyawan atau 36,4\% berjenis kelamin perempuan, sebagian besar rentang usia dibawah 30 tahun yaitu sebesar 32 orang $(36,4 \%)$, rentan usia 31-40 tahun yaitu sebesar 46 orang $(47,9 \%)$, rentan usia diatas 40 tahun yaitu sebesar 15 orang $(15,6)$, responden berstatus perkawinan lajang yaitu sebesar 21 orang $(21,8 \%)$, menikah yaitu sebesar 73 orang $(76,1 \%)$ dan duda/janda sebesar 2 orang $(2,1 \%)$, berdasarkan data yang diperoleh dari 96 responden karyawan PT. Varia Usaha sebagian besar responden berstatus kerja tetap yaitu sebesar 96 orang (100\%), responden memiliki pendidikan terakhir SMK/SMA yaitu sebesar 42 orang $(43,8 \%)$, diploma yaitu 20 orang $(20,8 \%)$, sarjana sederajad yaitu sebesar 34 orang $(35,4 \%)$, sebagian besar responden dalam rentan masa kerja dibawah 5 tahun yaitu sebesar 34 orang $(35,4 \%)$, rentan masa kerja 5-10 tahun yaitu sebesar 32 orang (33,3\%), rentan masa kerja diatas 10 tahun yaitu sebesar 30 orang $(31,3 \%)$.

Menurut Sufren dan Natanael (2014:62) butir pertanyaan dikatakan valid bila nilai 
korelasinya di atas atau sama dengan 0,2. Sedangkan untuk menguji reliabilitas alat ukur dinyatakan reliabel bila nilai korelasinya berkisar 0,6 sampai dengan 0,8 . Berdasarkan pengujian validitas yang telah dilakukan dari 21 item variabel motivasi kerja, 17 item variabel loyalitas, 6 item variabel kualitas karyawan, dan 12 item pertayaan varibel kinerja karyawan yang diujikan, item tersebut semuanya valid karena semua nilainya diatas 0,2 atau sama dengan 0,2. Reliabilitas untuk variabel motivasi kerja sebesar 0,908 , variabel loyalitas sebesar 0,844, variabel kualitas karyawan sebesar 0,778 , sedangkan variabel kinerja karyawan sebesar 0,862. Hasil uji reabilitas menunjukkan bahwa variabel motivasi kerja, loyalitas, kualitas karyawan dan kinerja karyawan dinyatakan reliabel karena memiliki nilai korelasi lebih besar 0,6. Analisis Statistik yang digunakan mengunakan p-plots untuk mengetahui data berdistribusi normal dengan melihat penyebaran data (titik) pada sumbu diagonal dan grafik normal. Dari ke empat variabel yaitu variabel mtivasi kerja, loyalitas, kualitas karyawan, kinerja karyawan semua variabel di katakana berdistribusi normal karena penyebaran data menyebar disekitar garis diagolnya.

Analisis regresi linier berganda dengan menggunakan program spss 18 for windows diperoleh hasil regresi berganda seperti tabe 1 menjelaskan hasil analisis regresi berganda variabel motivasi kerja, loyaitas dan kualitas karyawan

Tabel 1. Hasil Regresi Linier Berganda

\begin{tabular}{c|c|c|l|l|l}
\hline Model & B & $\begin{array}{c}\text { Std. } \\
\text { Error }\end{array}$ & Beta & T & Sig \\
\hline 1 (constants) & 6,183 & 3,118 & & 1,983 &, 050 \\
\hline $\begin{array}{c}\text { Motivasi } \\
\text { Kerja }\end{array}$ &, 041 &, 039 &, 076 & 1,056 &, 294 \\
\hline Loyalitas &, 230 &, 063 &, 314 & 3,672 &, 000 \\
\hline $\begin{array}{c}\text { Kualitas } \\
\text { Karyawan }\end{array}$ &, 983 &, 136 &, 552 & 7,211 &, 000 \\
\hline
\end{tabular}

Sumber: Output SPSS (data diolah peneliti, 2015).

Nilai konstanta $(\alpha)$ adalah 6,183 dapat diartikan bahwa apabila Motivasi kerja, Loyalitas, Kualitas Karyawan sama dengan 0 (nol), maka besarnya Kinerja karyawan adalah 6,183. Makna tanda positif pada konstanta adalah meskipun tidak ada Motivasi kerja, Loyalitas, Kualitas Karyawan maka Kinerja karyawan pada perusahaan PT. Varia Usaha Gresik tetap terjadi dengan nilai probabillitynya sebesar 6,183, Koefisien Regresi untuk Variabel Motivasi Kerja (X1) nilai 0,041 pada variabel motivasi kerja (X1) adalah bernilai negatif sehingga dapat dikatakan tidak ada pengarunya antara motivasi kerja dengan kinerja karyawan PT. Varia Usaha.

Koefisien Regresi untuk Variabel loyalitas (X2) nilai 0,230 pada variabel loyalitas (X2) adalah bernilai positif terhadap kinerja karyawan PT. Varia Usaha hal ini membuktikan bahwa apabila loyalitas yang di berikan karyawan PT Varia Usaha sangat tinggi maka hasil kinerja mereka juga akan lebih baik, Koefisien Regresi untuk Variabel kualitas karyawan (X3) nilai 0,983 pada variabel kualitas karyawan (X3) adalah bernilai positif terhadap kinerja karyawan PT. Varia Usaha sehingga dapat dikatakan bahwa semakin tinggi kualitas karyawan yang di miliki oleh karyawan PT Varia Usaha maka semakin tinggi pula hasil kinerja mereka. Pengujian hipotesis dengan uji f dan uji t, uji f untuk menentukan apakah variabel independen secara berasama-sama mempunyai pengaruh terhadap variabel dependen.

Tabel 2 Hasil Pengujian Hipotesis Untuk Uji Simultan

\begin{tabular}{c|c|c|c|c|c}
\hline & $\begin{array}{c}\text { Sum of } \\
\text { Squares }\end{array}$ & Dt & Mean Square & F & Sig \\
\hline Regresion & 1064,808 & 3 & 354,936 & 80,325 &, $000^{\mathrm{a}}$ \\
\hline
\end{tabular}




\begin{tabular}{c|c|c|c|c|c}
\hline Residual & 406,525 & 92 & 4,419 & & \\
\hline Total & 1471,333 & 25 & & & \\
\hline \multicolumn{7}{l}{ Sumber: Output SPSS (data diolah peneliti, 2015). }
\end{tabular}

Tabel di atas menunujukan nilai $\mathrm{F}$ hitung untuk variabel motivasi kerja (X1), loyalitas(X2), kualitas karyawan(X3) adalah sebesar 80,325 dengan angka signifikan (P value) sebesar $0,000<0,05$. Atas dasar perbandingan tersebut maka $\mathrm{H}_{0}$ ditolak dan $\mathrm{H}_{\mathrm{a}}$ diterima, sehingga variabel motivasi kerja(X1), loyalitas(X2), kualitas karyawan(X3) secara bersama -sama

mempunyai pengaruh yang signifikan secara terhadap variabel kinerja karyawan(Y).

Sedangkan untuk uji t pada dasarnya digunakan untuk melihat pengaruh variabel independen terhadap variabel dependen secara parsial, variabel yang akan di uji variabel motivasi kerja, variabel loyalitas, variabel kualitas karyawan, dibawah tabel bawah ini akan dijelaskan :

Tabel 3 Hasil Pengujian Hipotesis

Untuk Uji T-Test

\begin{tabular}{c|c|c|c|c|c|}
\hline \multirow{2}{*}{ Model } & $\begin{array}{c}\text { Undstandardized } \\
\text { coeffients }\end{array}$ & $\begin{array}{c}\text { Strandart- } \\
\text { zed }\end{array}$ & \multicolumn{2}{|c}{$\mathrm{T}$} & \multicolumn{2}{|c}{ Sig } \\
\cline { 2 - 5 } Constant & B error & Std. & Beta & \multicolumn{2}{|c}{ T } \\
\cline { 2 - 5 } & 6,183 & 3,118 & & 1,983 &, 050 \\
\hline $\begin{array}{c}\text { Motivasi } \\
\text { Kerja }\end{array}$ &, 041 &, 039 &, 073 & 1,056 &, 294 \\
\hline Loyalitas &, 230 &, 063 &, 314 & 3,672 &, 000 \\
\hline $\begin{array}{c}\text { Kualitas } \\
\text { Karyawan }\end{array}$ &, 983 &, 136 &, 552 & 7,211 &, 000 \\
\hline
\end{tabular}

Sumber: Output SPSS (data diolah peneliti, 2015).

Pengaruh yang tidak signifikan terhadap

Tabel diatas menunjukkan nilai $\mathrm{t}$ hitung untuk variabel Motivasi kerja (X1) adalah sebesar 1,056 dengan nilai signifikan sebesar 0,294 yang lebih besar dari 0,05 atau 5\%, maka $\mathrm{H}_{0}$ diterima dan $\mathrm{H}_{\mathrm{a}}$ ditolak, sehingga dapat dikatakan Motivasi kerja (X1) tidak mempunyai pengaruh terhadap Kinerja karyawan (Y), tabel diatas menunjukkan nilai t hitung untuk variabel Loyalitas (X2) adalah sebesar 3,672 didukung dengan nilai signifikan sebesar 0,000 lebih kecil dari 0,05 atau 5\%, maka $\mathrm{H}_{0}$ ditolak dan $\mathrm{H}_{\mathrm{a}}$ diterima, sehingga dapat dikatakan variabel Loyalitas (X2) mempunyai pengaruh yang signifikan terhadap Kinerja Karyawan (Y), Tabel diatas menunjukkan nilai $\mathrm{t}$ hitung untuk variabel Kualitas Karyawan (X3) adalah sebesar 7,211 didukung dengan nilai signifikan sebesar 0,000 lebih kecil dari 0,05 atau 5\%, maka $\mathrm{H}_{0}$ ditolak dan $\mathrm{H}_{\mathrm{a}}$ diterima, sehingga dapat dikatakan variabel Kualitas Karyawan (X3) mempunyai pengaruh yang signifikan terhadap Kinerja Karyawan (Y).

Uji asumsi klasik yang digunakan yaitu uji normalitas, uji multikolonieritas, uji heteroskedastisitas, dan uji linearitas. Uji normalitas untuk menguji apakah dalam sebuah model regresi, variabel terikat dan variabel bebas atau keduanya mempunyai distribusi normal. Jika data menyebar disekitar garis dan mengikuti arah garis diagonal maka model regresi memenuhi asumsi normalitas tetapi jika data menyebar jauh dari garis diagonal dan atau mengikuti arah garis diagonal maka model regresi tidak memenuhi asumsi normalitas, untuk ke tiga variabel bebas yaitu variabel motivasi kerja, loyalitas, kualitas karyawan di katakan berdistribusi normal karena ketiga variabel ini memiliki penyebaran titik-titik disekitar garis dan mengikuti arag garis diagonalnya.

Uji multikolonieritas dilakukan untuk menguji apakah pada model regregi ditemukan adanya korelasi antar variabel bebas, dari ketiga variabel bebas ini menunjukan semua variabel berdistribusi normal karena memiliki nilai signifikan lebih besar dari 0,05. Nilai tolerance lebih besar dari 10 persen $(0,1)$. Hasil perhitungan VIF juga menunjukan bahwa nilai masing-masing variabel kurang dari 10, jadi dapat disimpulkan bahwa tidak ada multikolinieritas antar variabel bebas.

Pola penyebaran residual pada Scatterplot menyebar dan tidak membentuk 
pola menunjukan bahwa tidak terjadi heteroskedastisitas. Uji linearitas untuk mengetahui apakah dua variabel mempunyai hubungan yang linearitas atau tidak secara signifikan pada tabel dibawah dapat dijelaskan apakah $\mathrm{f}$ hitung variabel motivasi, loyalitas, dan kualitas karyawan lebih besar dari pada nilai probabilitasnya.

Tabel 4 Hasil Uji Linieritas Variabel

\begin{tabular}{c|c|c|c|c|c}
\multicolumn{7}{c|}{} & $\begin{array}{c}\text { Sum Of } \\
\text { squres }\end{array}$ & Df & $\begin{array}{c}\text { Mean } \\
\text { Square }\end{array}$ & F & Sig \\
\hline $\begin{array}{c}\text { Between } \\
\text { groups } \\
\text { (combined) }\end{array}$ & 68,433 & 58 & 1,180 & 1,611 &, 062 \\
\hline Linearity & 27,009 & 1 & 29,009 & 36,878 &, 000 \\
\hline $\begin{array}{c}\text { Deviation } \\
\text { from } \\
\text { linearity }\end{array}$ & 41,425 & 57 &, 727 &, 992 &, 519 \\
\hline $\begin{array}{c}\text { Within } \\
\text { groups }\end{array}$ & 27,098 & 37 &, 372 & & \\
\hline Total & 95,532 & 95 & & & \\
\hline
\end{tabular}

Sumber: Output SPSS (data diolah peneliti, 2015).

Pada tabel di atas dapat disimpulkan

bahwa $f$ hitung motivasi memiliki nilai probabilitas $0,992>0,05$ dengan nilai probabilitasnya lebih besar maka dapat disimpulkan bahwa ada hubungan yang linear antara motivasi kerja dengan kinerja karyawan.

Tabel 5 Hasil Uji Linieritas Variabel Loyalitas

\begin{tabular}{c|c|c|c|c|c}
\hline & Sum Of squres & Df & $\begin{array}{c}\text { Mean } \\
\text { Square }\end{array}$ & F & Sig \\
\hline $\begin{array}{c}\text { Between } \\
\text { groups } \\
\text { (combined) }\end{array}$ & 77,971 & 62 & 1,258 & 2,363 &, 004 \\
\hline Linearity & 47,590 & 1 & 47,590 & 89,432 &, 000 \\
\hline $\begin{array}{c}\text { Deviation } \\
\text { from } \\
\text { linearity }\end{array}$ & 30,381 & 61 &, 498 &, 936 &, 597 \\
\hline $\begin{array}{c}\text { Within } \\
\text { groups }\end{array}$ & 17,560 & 33 &, 532 & & \\
\hline Total & 95,532 & 95 & & & \\
\hline
\end{tabular}

Sumber: Output SPSS (data diolah peneliti, 2015).

Pada tabel dapat disimpulkan bahwa $\mathrm{f}$ hitung variabel loyalitas memiliki nilai probabilitas $0,936>0,05$ dengan nilai

probabilitasnya lebih besar maka dapat disimpulkan bahwa ada hubungan yang linear antara loyalitas dengan kinerja karyawan.

Tabel 6 Hasil Uji Linieritas Variabel Kualitas Karyawan

\begin{tabular}{c|c|c|c|c|c}
\hline & Sum Of squres & Df & $\begin{array}{c}\text { Mean } \\
\text { Square }\end{array}$ & F & Sig \\
\hline $\begin{array}{c}\text { Between } \\
\text { groups } \\
\text { (combined) }\end{array}$ & 59,332 & 9 & 6,591 & 15,655 &, 000 \\
\hline Linearity & 57,851 & 1 & 57,851 & 137,400 &, 000 \\
\hline $\begin{array}{c}\text { Deviation } \\
\text { from } \\
\text { linearity }\end{array}$ & 1,471 & 8 &, 184 &, 437 &, 896 \\
\hline
\end{tabular}




\begin{tabular}{c|c|c|c|c|c}
\hline $\begin{array}{c}\text { Within } \\
\text { groups }\end{array}$ & 36,209 & 86 & 421 & & \\
\hline Total & 95,532 & 95 & & & \\
\hline
\end{tabular}

Pada tabel di atas dapat disimpulkan

bahwa f hitung kualitas karyawan memiliki nilai probabilitas $0,437>0,05$ dengan nilai probabilitasnya lebih besar maka dapat disimpulkan bahwa ada hubungan yang linear antara kualitas karyawan dengan kinerja karyawan.

\section{Pengaruh Motivasi Kerja Terhadap Kinerja Karyawan}

Hasil penelitian menunjukkan bahwa melalui hasil analisis $\mathrm{Uji} \mathrm{t}$ menunjukkan bahwa motivasi kerja (X1) tidak berpengaruh signifikan terhadap Kinerja karyawan (Y). Hal ini dibuktikan dengan nilai signifikannya lebih besar, yang menunjukkan bahwa hipotesis pertama ditolak karena hipotesisnya yaitu "Motivasi kerja tidak berpengaruh signifikan terhadap kinerja karyawan pada perusahaan PT. Varia Usaha Gresik". Menurut jawaban kuisioner rata- rata karyawan PT. Varia Usaha memilih indikator kesempatan berprestasi dan gaji yang paling banyak dipilih oleh responden yang memilih setuju dengan kata lain yang mempengaruhi motivasi kerja karyawan PT. Varia Usaha adalah kesempatan berprestasi dan gaji.

Hasil ini sejalan dengan penelitian yang dilakukan Dhermawan dkk. (2012)motivasi kerja tidak berpengaruh signifikan terhadap kinerja karyawan. Penelitian Murti (2013) motivasi kerja tidak berpengaruh signifikan terhadap kinerja karyawan.

\section{Pengaruh Loyalitas Terhadap Kinerja Karyawan}

Hasil penelitian menunjukkan bahwa melalui hasil analisis Uji $\mathrm{t}$ menunjukkan bahwa Loyalitas (X2) berpengaruh positif terhadap Kinerja karyawan (Y), yang menunjukkan bahwa hipotesis kedua yaitu "Loyalitas berpengaruh positif terhadap kinerja karyawan pada perusahaan PT. Varia Usaha Gresik“ terbukti kebenarannya. Hal ini dibuktikan dengan nilai signifikansi lebih kecil. Besarnya pengaruh loyalitas terhadap kinerja karyawan sangatlah berpengaruh semakin tinggi loyalitas maka akan berdampak semakin tinggi kinerja karyawan.
Realita yang ada di perusahaan untuk mendorong karyawan perusahaan memberikan berbagai motivasi agar karyawan merasa dihargai, motivasi yang yang di berikan adalah memberikan penghargaan kepada karyawan yang sudah bekerja keras, berdedikasi tinggi kepada perusahaan, mau bekerja keras dengan tim, bertangung jawab akan pekerjaan. Dengan memberikan penghargaan kenaikan jabatan, memberikan penghargaan uang dan memberikan tiket umroh gratis penghargaan ini yang di berikan PT. Varia Usaha. Hasil ini sejalan dengan penelitian Preko (2013), Setiyono (2009) dan Hamzah (2013) yang menyatakan loyalitas berpengaruh terhadap kinerja karyawan.

\section{Pengaruh Kualitas Karyawan Terhadap Kinerja Karyawan}

Hasil penelitian menunjukkan bahwa melalui hasil analisis Uji t menunjukkan bahwa kualitas karyawan (X3) berpengaruh positif terhadap Kinerja karyawan (Y), hal ini dibuktikan dengan nilai signifikan lebih kecil yang menunjukkan bahwa hipotesis ketiga yaitu "Kualitas Karyawan berpengaruh positif terhadap kinerja karyawan pada perusahaan PT. Varia Usaha Gresik“ terbukti kebenarannya. Besarnya pengaruh kualitas karyawan terhadap kinerja karyawan dapat dilihat dari nilai koefisien regresi yang tinggi hasil tersebut menunjukkan semakin tinggi kualitas karyawan maka akan berdampak semakin tinggi kinerja karyawan.

Berdasarkan hasil responden melalu pernyataan-peryataan dalam mengukur kualitas karyawan PT. Varia Usaha nilai yang paling diminan dan paling tinggi nilainya adalah indikator skill dan Abilities maka dapat disimpulkan bahwa kualitas karyawan berpengaruh terhadap kinerja karyawan. Khususnya skill dan Abilities yang sangat dominan dalam pernyataan kuisioner. Hasil ini sejalan dengan penelitian Nadirsyah (2010) loyalitas berpengaruh terhadap kinerja karyawan. 


\section{Pengaruh Motivasi Kerja, Loyalitas, Dan Kualitas Karyawan Terhadap Kinerja Karyawan}

Hasil penelitian menunjukan bahwa secara bersama-sama (simultan) motivasi kerja, loyalitas, kualitas karyawan berpengaruh positif signifikan terhadap kinerja karyawan pada perusahaan PT. Varia Usaha Gresik, didukung dengan nilai signifikan lebih kecil dengan demikian Ho ditolak, dan Ha diterima artinya bersamasama variabel bebas yang terdiri dari motivasi kerja (X1), loyalitas (X2), kualitas karyawan (X3) berpengaruh terhadap variabel terikat yaitu kinerja karyawan (Y) PT. Varia Usaha Gresik.

\section{KESIMPULAN}

Berdasarkan hasil analisis dapat disimpulkan bahwa karyawan PT. Varia Usaha yang berjumlah 96 karyawan dengan judul penelitian "Pengaruh Motivasi Kerja, Loyalitas, Dan Kualitas Karyawan Terhadap Kinerja Karyawan PT. Varia Usaha" berdasarkan uraian dan penjelasan yang telah dikemukakan pada bab-bab sebelumnya, maka dapat ditarik kesimpulan sebagai berikut : Secara parsial variabel motivasi kerja tidak berpengaruh signifikan terhadap kinerja karyawan PT. Varia Usaha. Secara parsial variabel loyalitas berpengaruh signifikan terhadap kinerja karyawan PT. Varia Usaha. Secara parsial variabel kualitas karyawan berpengaruh signifikan terhadap kinerja karyawan. Secara simultan/bersamasama variabel motivasi kerja, variabel loyalitas, variabel kualitas karyawan berpengaruh signifikan terhadap kinerja karyawan.

Berdasarkan hasil penelitian, maka dapat dikemukakan beberapa saran Bagi perusahaan Membuat rangking penilaian kerja di setiap biro dan di perlihatkan setiap satu bulan sekali di mading biro-biro tersebut agar karyawan yang memiliki ranking kerja yang rendah akan memperhatikan dan berusaha agar di bulan berikutnya tidak terendah lagi, dan setiap orang yang mendapatkan nilai yang tinggi maka karyawan tersebut mendapatkan hadiah dari biro tersebut hal ini pasti bisa membuat karyawan terpacu untuk mendapatkan nilai yang tinggi dan mendapatkan hadiah. Disarankan untuk perusahaan memberikan kesempatan bagi seluruh karyawan khususnya bagi kandidat karyawan teladan, bukan hannya untuk para pemenang audisi karyawan teladan saja yang mendapatkan promosi jabatan. Harusnya memberi kesempatan bagi seluruh kandidat karyawan teladan untuk mendapatkan promosi jabatan, karena untuk menjadi kandidat karyawan teladan harus karyawan yang berdedikasi yang tinggi dan kemampuan yang baik. Jadi sayang apabila perusahaan tidak melihat potensi karyawan lainya dan hanya memberi kesempatan karier kepada pemenang. Hal ini diakukan agar karyawan yang baik ini semakin loyal, semakin berkompetensi dan kinerjanya baik dan memuaskan.

Disarankan kepada perusahaan untuk selalu memperhatikan absensi karyawan dan memberikan sangsi yang tegas apabila dalam 1 bulan melakukan keterlambatan maka harus ada teguran dari atas biro mereka masingmasing dan dari departemen sumber daya manusia.

Bagi peneliti selanjutnya dapat disarankan untuk melakukan penelitan motivasi kerja, loyalitas, kualitas karyawan dibidang jasa maupun produksi yang lain dan agar peneliti selanjutnya memperluas variabel dan memperdalam lagi indikatorindikator yang dipergunakan sehingga dapat lebih meningkatkan hasil yang diperoleh saat penelitian.

\section{RFERENSI}

Achmad S, Ruky. 2006. Manajemen Pengajian dan Pengupahan untuk Karyawan Perusahaan. Jakarta: PT. Gramedia Pustaka Utama.

Azwar, Saifuddin. 2012. Penyusunan Skala Psikologi (Edisi kedua). Yogyakarta: Pustaka Pelajar.

Gibson, James L., Invancevich, John M., dan Donnelly, Jame H. Jr.,2001. Organisasi, alih bahasa Ir. Nunuk Ardiani, MM. Jakarta : Bina Aksara.

Hamzah Muriko Febrian, Musadieq al. Mochammad, Hakam M. Soe'oed, 2013. Pengaruh Senioritas dan Loyalitas Terhadap Promosi (Studi Pada Karyawan PT. Pembangunan 
DVO III Surabaya. Jurnal Administrasi Bisnis. Vol.6, No.2.

Handoko, T Hani, 2010. Manajemen Personalia dan Sumber Daya Manusia. Edisi 2. Yogyakarta : BPFE.

Hasibuan, M, 2003. Organisasi dan Motivasi: Dasar Peningkatan Produktivitas. Jakarta : Bumi Aksara. Hasibuan, SP, M, 2005. Manajemen Sumber Daya Manusia. Yogyakarta : Bumi Aksara

Malthis, Robert L. Jackson, John H, 2001. Manajemen Sumber Daya Manusia Buku I. Jakarta: Salemba Empat. Matutina, 2001. Manajemen Sumber Daya Manusia cetakan kedua. Gramedia Widia Sarana Indonesia. Jakarta.

Mangkunegara, Anwar Prabu, 2005. Perilaku dan Budaya Organisasi.Cetakan Pertama. Bandung : PT. Refika Aditama.

Nadirsyah, 2010. Pengaruh Pegawai, Motivasi Kerja dan Lingkungan Kerja Terhadap Kinerja Pegawai Dinas Kebudayaan dan Parawisata Propinsi Kepulauan Bangka Belitung. Tesis tidak diterbitkan. Pangkal pinang : Universitas Terbuka.

Business and management. Vol.6, NO.5.

Utomo joko, Suwardi, 2011. Pengaruh Motivasi Kerja, Kepuasan Kerja dan Komitmen Organisasional Terhadap Pegawai Setda Kabupaten Pati. Jurnal Riset Manajemen dan Akuntansi. Vol.5, No.1
Nitasari, Rizka Afresalia, 2012. Analisis Pengaruh Terhadap Kinerja Karyawan Dengan Kepuasan Kerja Sebagai Variabel Intervening Pada PT. Bank Central asi Tbk. Cabang kudus. Tesis tidak diterbitkan. Semarang: Universitas Diponegoro.

Preko, Alexander, and Jhon Adjetey, 2013. A Study On The Concept Of Employee Loyality and Engagement on the Performance of Sales Executives of Commercial Banks in Ghana. International journal of business research and management. Vol. 4, BO.2.

Saydam, Ghozali, 2000. Manajemen Sumber Daya Manusia : Suatu Pendekatan Mikro, Djambantan. Jakarta.

Sugiono, 2009. Statistika Untuk Penelitian. Cetakan Keempat belas, Bandung : Alfabet.

Sufren, Natanael Yonathan. 2014. Belajar Otodidak SPSS Pasti Bisa. Jakarta: PT. Elex Media Komputindo.

Umar, Akmal, 2012. Pengaruh Upah, Motivasi Kerja Terhadap Kinerja Pekerja pada Industri Manufaktur di Kota Makasar. European Journal of 